\title{
RESEARCH ON EXTENDING THE SHELF LIFE UP TO 7 DAYS OF HEAT-TREATED MEAT PRODUCTS, MANUFACTURED ACCORDING TO COMPANY'S STANDARDS AND TECHNOLOGICAL INSTRUCTIONS IN FORCE BY THE LOCAL PRODUCER
}

\author{
Pîrlog Alisa Emilian \\ $\mathrm{PhD}$, associate professor \\ State Agrarian University of the Republic of Moldova \\ ORCID: 0000-0003-3937-8708 \\ E-mail: morarialisa@yahoo.com \\ Curchi Diana Vasile \\ $\mathrm{PhD}$, head of laboratory \\ National Centre for Veterinary Diagnostics \\ ORCID: 0000-0003-3937-8708 \\ E-mail: curchi_diana@mail.ru
}

In contemporary market conditions, quality has become a key element in meeting consumer requirements. Of particular interest is the manufacture of products with high organoleptic characteristics, which have a long sales prospect, with long shelf life, without changing the product quality. In order to achieve safe and qualitatively nutritious products, we need the latest raw materials and technologies. Establishing the validity of these products over a period of time helps to market foodstuffs that are safe for consumption and from the point of view of producers' economic and food safety considerations. The research was performed on assortments of sausages made of heat-treated ingredients, such as: Lebărvurști, c / I - packed in natural membrane; Boiled pork toba - packed in polyamide, Pork Saltison - packed in natural membrane, made for public consumption. The purpose of the research was to determine the quality, physico-chemical and microbiological indices in order to study the possibility of extending the shelf life of meat products up to 7 days, the meat products were manufactured in accordance with the company's standards and technological instructions in force of the meat processor. Thus, there were obtained very good results, related to the organoleptic characteristics such as: external appearance, consistency, odor, color that correspond to the requirements of the norms stipulated in the normative acts in force for these products; the same can be said for the physical indices, since they have not changed considerably over time, remaining within the normative requirements even at the end of the shelf life, not affecting the quality of the product. And in terms of microbiological indications, it is noteworthy that throughout the shelf life of the product (7 days) they have not been modified and have corresponded to the requirements of the normative documents.

Key words: meat products, quality, safety, shelf life

DOI: https://doi.org/10.32845/bsnau.lvst.2021.2.5

Food industry presents a renewal and a diversity of food products based on the desire to meet consumers' demands.

Consumers have the right to quality food that directly influence their life quality. The issue of food quality is constantly considered by the bodies set up to ensure its safety and to protect the consumers' interests.

In order to achieve safe and qualitatively nutritious products, we need the latest raw materials and technologies. Establishing the validity of these products over a period of time helps to market foodstuffs that are safe for consumption and also from the point of view of producers' economic and food safety considerations.

In contemporary market conditions, quality has become a key element in meeting consumers' requirements. Of particular interest is the manufacture of products with high organoleptic characteristics that have a long sales prospect, with long shelf life, without quality change.

The stability of foodstuffs, including meat products, refers to their ability to retain their initial (qualitative and quantitative) characteristics over time and to their resistance to handling and transport. It is limited in time, being determined by the substances in the composition of the products, with different degrees of lability, both under the incidence of interactions with

other component substances, and under the incidence of some environmental factors.

Material and method. The investigations were carried out in the Laboratory of Testing food products of animal origin LTFPAO of IPCRDV (accredited according to SM SR EN ISO / CEI 17025: 2006 in the National System of Conformity Assessment of the Republic of Moldova, accreditation certificate no. LI - 004).

The following samples of heat-treated sausages were subjected to investigations: Lebarvurști, $\mathrm{c} / \mathrm{l}$; packed in natural membrane; Boiled pork toba - packed in polyamide and Pork Saltison -packed in natural membrane. 4 samples of each product were taken from four different manufacturing data (four batches) - 27.02.20, 04.03.20, 13.03.20, 27.03.20.

The research was based on the complex study in dynamics of physico-chemical and microbiological quality indices in order to establish the shelf life: 7 days at $t^{\circ} \mathrm{C}=+0+$ $6{ }^{\circ} \mathrm{C}$ and the relative humidity of the air of $\max .=75 \%$.

For the study there were presented samples of meat products, manufactured according to company standards and technological instructions, with complex compositions and different packaging, according to Table 1. 
Table 1

Composition and packaging of heat-treated sausages

\begin{tabular}{|l|l|l|l|l|}
\hline Nr. & \multicolumn{1}{|c|}{ Product name } & \multicolumn{1}{|c|}{ Composition } & \multicolumn{1}{c|}{ Packaging } & \multicolumn{1}{c|}{$\begin{array}{c}\text { Existing shelf life } \\
\text { according to IT }\end{array}$} \\
\hline 1. & Pork Saltison & pork head, pork organs & Natural membrane & 24 hours \\
\hline 2. & Boiled pork toba & pork meat & Polyamide & 48 hours \\
\hline 3. & Lebarvurști , cll; & pork meat, bacon, liver, heart, kidneys & Natural membrane & 48 hours \\
\hline
\end{tabular}

Storage conditions - the research samples were stored in the laboratory at $\mathrm{t}^{\circ} \mathrm{C}=+0+6^{\circ} \mathrm{C}$ and at the relative air humidity of $\max .=75 \%$ (conditions indicated by the manufacturer).

Periodicity of research - the research period of the product, according to the requirements of the regulatory documents must exceed the required shelf life (7 days), supplemented by a period of time ( +3.5 days) calculated depending on the reserve coefficient (in this case 1.5).

The research periods of sausages made of heat-treated ingredients prepared according to the company's standards and technological instructions of the manufacturer were: initially; 5 days, 7 and 10 days.

The investigations were performed according to the classical, gravimetric, volumetric, spectrophotometric and microbiological reference methods, based on ISO standards, for each quality and microbiological index.

The investigations were always carried out in intact packaging, not previously opened.

Results and discussions. Whereas meat and meat products, after collection, during preservation, storage and disposal are exposed to the action of physical, chemical and microbiological factors, which may produce changes in organoleptic, physico-chemical and microbiological aspects and which limit their shelf life, it is necessary to know the dynamics of these changes and the main factors that produce them.

If the organoleptic and harmlessness indices must remain practically unchanged throughout the storage period, then the microbiological and physico-chemical indices may change within the limits of the requirements of sanitary norms and rules.

The establishment and argumentation of the validity term requires the complex study of the processes that take place in the product during its storage, in the conditions indicated by the normative document.

\section{Organoleptic indices}

In accordance with GD no. 720 of 28.06.2007 on the approval of the Technical Regulation "Meat products" and the normative document for each product, there were determined yhe following organoleptic indices: appearance, appearance in section, taste and odor, color for all samples for each research period.

The sausages made of heat-treated ingredients initially met the requirements of the normative documents in force (GD no. 720 and CS): these were bars with a clean, dry surface, without damage and adhesions of composition, without stains. In the section they were of uniform color throughout the whole mass, characteristic of each type of product, evenly mixed, without gaps. Elastic consistency. Pleasant odor, in some products with a slight aroma of spices, without a foreign smell. Pleasant taste, salty enough, slightly spicy, without foreign taste.

At the end of the storage period, the organoleptic characteristics of the products did not change. Smooth, spotless, non-sticky membrane, adherent in composition. In the section without color changes, both in the mass of the product and in the peripheries. Pleasant odor, characteristic of each type of product, without foreign odor. Pleasant taste, salty enough, slightly spicy, without foreign taste.

Thus, at the expiration of the shelf life (7 days), the organoleptic properties of meat products did not change: the appearance, color, taste and odor were the same.

The performed organoleptic assessment led to the formulation of the following conclusions: the samples investigated during storage did not lose their organoleptic properties and according to the organoleptic characteristics correspond to the normative documents in force.

\section{Physico-chemical indices}

Initially, the quality indices of meat products (table $2 ; 3$ ) were evaluated in accordance with the normative requirements according to GD no. 720 of 2007, GD no. 229 of 2013 and the Manufacturer's Company Standard (CS).

Quality indices of cooked meat products

Table 2

\begin{tabular}{|c|c|c|c|c|c|}
\hline \multirow{3}{*}{ Examined indices } & \multirow{3}{*}{ Test method } & \multicolumn{3}{|c|}{ Admissible requirements ( GD nr.720/CS) / Obtained results } & \multirow{3}{*}{ Conformity } \\
\hline & & $\begin{array}{l}\text { Boiled pork toba, } \\
\mathrm{c} / \mathrm{s},(\mathrm{n}=4)\end{array}$ & $\begin{array}{c}\text { Pork Saltison, } \\
\text { c/l, }(n=4)\end{array}$ & $\begin{array}{c}\text { Lebărvurssti } \\
\text { c/l, }(n=4)\end{array}$ & \\
\hline & & $X \pm S x$ & $X \pm S x$ & $X \pm S x$ & \\
\hline Protein mass fraction, & ISח 027 & $10 / 10$ & $10 / 10$ & $7,0 / 7,0$ & A mondang \\
\hline$\%$, min. & - 150951 & $17,820 \pm 0,150$ & $15,450 \pm 0,120$ & $8,930 \pm 0,052$ & Accordanice \\
\hline Fat mass fraction, $\%$ & ISO 1442.2012 & $35 / 35$ & $\mathrm{n} / \mathrm{r} / 10,0$ & $40 / 40$ & Accordanco \\
\hline $\max$. & -1501443.2012 & $17,90 \pm 0,075$ & $8,580 \pm 0,060$ & $34,720 \pm 0,161$ & Accordance \\
\hline Starch mass fraction, & -GOST 10574 & $n / r^{*} / n / a^{*}$ & $\mathrm{n} / \mathrm{r} / 2,0$ & $5 / 5$ & Accordance \\
\hline$\%, \max$ & -GUSI 105/4 & absent & $1,233 \pm 0,011$ & $1,840 \pm 0,013$ & Accordance \\
\hline Chlorides mass fraction, & COST $0957-73$ & $2,7 / 3$ & $2-6 / 2-6$ & $2,5 / 3,0$ & Acrordance \\
\hline$\%, \max$ & $-G U S 1$ y95/-13 & $1,920 \pm 0,013$ & $2,560 \pm 0,018$ & $1,850 \pm 0,014$ & Accordance \\
\hline
\end{tabular}

The conformity of the cooked meat products was found, regarding the quality indices - the mass fraction of protein, fat starch, chlorides, phosphates and nitrites, in accordance with the requirements of the normative documents, which indicates that the products can be consumed within the initially established shelf life. 
It should be noted that the indices related to the mass fraction of phosphates and the mass fraction of nitrites also showed results that fall within the requirements of the regulations for this category of products (Table 3 ).

Subsequently, the samples of meat products from the four manufacturing dates were subjected to research at the initial stage and over 5,7 and 10 days of storage, regarding the assessment of organoleptic, physico-chemical and microbiological indices, indices that may affect the quality of the product during storage period.

Thus, following the initial investigations, it has been established that the products correspond to the requirements of the normative documents: RT "Meat products" GD No. 720 of 28.06.2007, GD no. 221 of 16.03 .2009 "Rules on microbiological criteria for food products" and company's standards for given products. It was stated that the products can be kept for further research.

Quality indices of cooked meat products under study

\begin{tabular}{|c|c|c|c|c|c|}
\hline \multirow{3}{*}{ Examined indices } & \multirow{3}{*}{ Test method } & \multicolumn{3}{|c|}{ Admissible requirements ( GD nr.720/CS) / Obtained results } & \multirow{3}{*}{ Conformity } \\
\hline & & $\begin{array}{c}\text { Boiled pork toba } \\
c / s,(n=4)\end{array}$ & $\begin{array}{l}\text { Pork Saltison, } \\
\text { cll. }(n=4)\end{array}$ & $\begin{array}{l}\text { Lebărvurşti } \\
\text { c/l. }(n=4)\end{array}$ & \\
\hline & & $X \pm S x$ & $X \pm S x$ & $X \pm S x$ & \\
\hline \multirow{2}{*}{$\begin{array}{c}\text { Phosphate mass } \\
\text { fraction, } \mathrm{mg} / \mathrm{kg} \text {, max }\end{array}$} & \multirow{2}{*}{ ISO 13730} & $5000 / 5000$ & $5000 / 5000$ & $5000 / 5000$ & \multirow{2}{*}{ Accordance } \\
\hline & & $1378,16 \pm 8,020$ & $1454,0 \pm 7,502$ & $1987,0 \pm 11,450$ & \\
\hline \multirow{2}{*}{$\begin{array}{c}\text { Nitrites mass fraction, } \\
\mathrm{mg} / \mathrm{kg} \text {, } \max \end{array}$} & \multirow{2}{*}{ GOST 8558.1-78 } & $150 / 50$ & $150 / 50$ & $150 / 50$ & \multirow{2}{*}{ Accordance } \\
\hline & & $42,0 \pm 0,282$ & $28,7 \pm 0,175$ & $36,8 \pm 0,266$ & \\
\hline
\end{tabular}

Subsequently, at intervals determined by time, in the samples from four manufacturing dates: 27.02.2019; 04.03.2019, 13.03.2019 and 27.03.2019 there was analyzed, in dynamics, the physico-chemical index - the mass fraction of humidity, $\%$.
It has been stated that for boiled pork toba; the initial humidity varied between $54.1 \%-56.9 \%$ at all reference data, these values fall within the admissible limits of the normative requirements in force (Table 4) for products with different manufacturing dates.

Table 4

Dynamics of physico-chemical indices - humidity, $\%$ in the studied samples during the storage period (10 days)

\begin{tabular}{|c|c|c|c|c|c|c|c|}
\hline Nr. & Sample & Shelf life, days & $\begin{array}{l}\text { Normative requirements } \\
\text { GD no.720/CS }\end{array}$ & \multicolumn{4}{|c|}{$\begin{array}{c}\text { Humidity, } \% \\
\text { SM SR ISO 1442:2014 }\end{array}$} \\
\hline \multicolumn{3}{|c|}{ Date of production } & & 27.02 .20 & 04.03 .20 & 13.03 .20 & 27.03 .20 \\
\hline \multicolumn{8}{|c|}{ Sausages made of heat-treated ingredients: } \\
\hline \multirow{4}{*}{1} & \multirow{4}{*}{$\begin{array}{l}\text { Boiled } \\
\text { pork toba }\end{array}$} & Initially & \multirow{4}{*}{$\max .60,0 / 60,0$} & 54,1 & 56,4 & 56,7 & 56,9 \\
\hline & & 5 & & 53,4 & 55,6 & 55,9 & 56,02 \\
\hline & & 7 & & 53,3 & 55,4 & 55,7 & 55,80 \\
\hline & & 10 & & 52,8 & 55,2 & 54,8 & 55,01 \\
\hline & \multirow{2}{*}{\multicolumn{3}{|c|}{$\begin{array}{l}\text { Difference between initial and } 10 \text { days of storage. } \\
\qquad X \pm S x\end{array}$}} & 1,3 & 1,2 & 1,9 & 1,89 \\
\hline & & & & $53,40 \pm 0,42$ & $55,650 \pm 0,35$ & $55,775 \pm 0,305$ & $55,932 \pm 0,382$ \\
\hline \multicolumn{8}{|c|}{$\begin{array}{c}\text { Reproducibility, } R, \%=2,77 \times S_{R}=1,8 \\
\text { Standard deviation of reproducibility, } S_{R}, \%=0,66 \\
\text { Compound standard uncertainty }(k=95 \%) U, \%=1,3\end{array}$} \\
\hline
\end{tabular}

\section{Cerinte Stat}

Rezultate obținute 27.03 .20

Rezultate obținute 13.03 .20

Rezultate obținute 04.03 .20

Rezultate obținute 27.02 .20

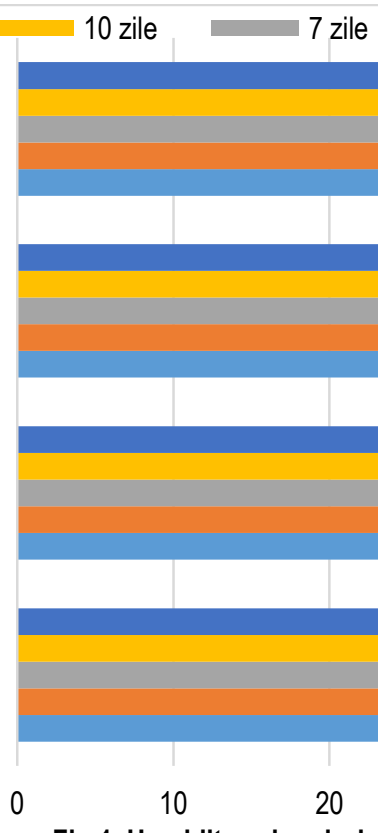

Fig.1, Humidity value during

State reqiurements

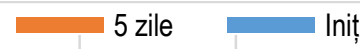


At the end of the storage period, after 10 days, these values were between $52.8 \%$ - $55.01 \%$, these data show an insignificant decrease in the humidity mass fraction at the end of the storage period. This process is specific to meat products during the storage period.

Thus, the products at the end of the storage period had humidity values of $52.8-55.01 \%$, which corresponded to the requirements of the normative document GD no. 720 of 28.06.2007 and CS for each product respectively.

For the range of boiled pork saltison product - the initial humidity ranged from $56.6 \%-59.1 \%$ to all reference data, these results fall within the permissible limits of the regulatory requirements in force for these products (Table 5).

Analysing the data from the table we can observe that with the advancement of the storage period the humidity content decreases, but with insignificant values, varying between $1.1 \%$ initially and up to $1.9 \%$ at 10 days of storage. After 10 days of storage, these indices were between $55.5 \%-57.2 \%$, the results attest to an insignificant decrease of humidity mass fraction at the end of the storage period, which confirms that the results obtained fall within the admissible limits of the normative acts in force, GD no. 720 of 28.06.2007 and CS to this category of products, taking into account the period and conditions of storage of cooked meat products.

Table 5

Dynamics of physico-chemical indices - humidity, $\%$ in the studied samples during the storage period (10 days)

\begin{tabular}{|c|c|c|c|c|c|c|c|}
\hline Nr. & Sample & $\begin{array}{c}\text { Shelf life, } \\
\text { days }\end{array}$ & $\begin{array}{c}\text { Normative requirements } \\
\text { GD no. } 720 / C S\end{array}$ & \multicolumn{4}{|c|}{$\begin{array}{c}\text { Humidity, } \% \\
\text { SM SR ISO 1442:2014 }\end{array}$} \\
\hline \multicolumn{3}{|c|}{ Date of production } & & 27.02 .20 & 04.03 .20 & 13.03 .20 & 27.03 .20 \\
\hline \multicolumn{8}{|c|}{ Sausages made of heat-treated ingredients: } \\
\hline \multirow{4}{*}{1} & \multirow{4}{*}{$\begin{array}{l}\text { Pork } \\
\text { Saltison }\end{array}$} & Initially & \multirow{4}{*}{$\max .70,0$} & 56,6 & 62,2 & 59,8 & 59,1 \\
\hline & & 5 & & 56,2 & 61,8 & 59,2 & 58,3 \\
\hline & & 7 & & 55,8 & 61,4 & 58,5 & 57,6 \\
\hline & & 10 & & 55,5 & 61,0 & 58,1 & 57,2 \\
\hline \multicolumn{4}{|c|}{ Difference between initial and 10 days of storage. } & 1,1 & 1,2 & 1,7 & 1.9 \\
\hline \multicolumn{4}{|c|}{$X \pm S x$} & $56,025 \pm 0,295$ & $61,60 \pm 0,432$ & $58,90 \pm 0,330$ & $58,050 \pm 0,401$ \\
\hline \multicolumn{8}{|c|}{$\begin{array}{c}\text { Reproducibility, } R, \%=2,77 \times S_{R}=1,8 \\
\text { Standard deviation of reproducibility, } S_{R}, \%=0,65 \\
\text { Compound standard uncertainty }(k=95 \%) \cup, \%=1,3\end{array}$} \\
\hline
\end{tabular}

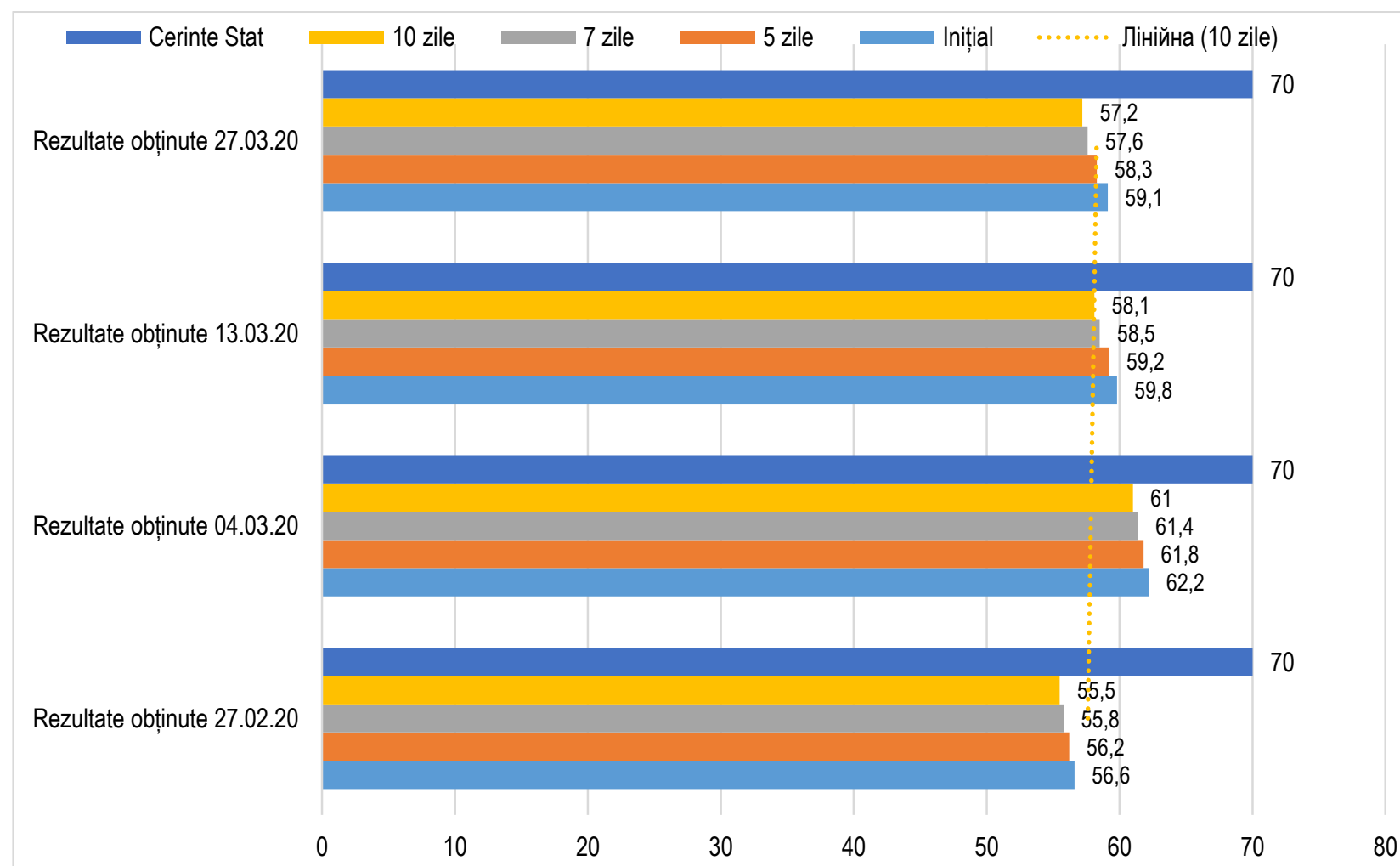

Fig. 2 Humidity value during the storage period \%, -Pork saltison

\section{State reqiurements 10 days 7 days 5 days Initially Linear(10 days)}

Regarding the results obtained for the assortment of boiled meat product Lebărvurști - the initial humidity varied between $61.8 \%$ - $58.2 \%$ for all reference data, these values fall within the admissible limits of the normative requirements in force for these products (table 6). 
Table 6

Dynamics of physico-chemical indices - humidity, $\%$ in the studied samples during the storage period (10 days)

\begin{tabular}{|c|c|c|c|c|c|c|c|}
\hline Nr. & Sample & $\begin{array}{c}\text { Shelf life, } \\
\text { days }\end{array}$ & $\begin{array}{c}\text { Normative requirements } \\
\text { GD no. } 720 / C S\end{array}$ & \multicolumn{4}{|c|}{$\begin{array}{c}\text { Humidity, \% } \\
\text { SM SR ISO 1442:2014 }\end{array}$} \\
\hline \multicolumn{3}{|c|}{ Date of production } & & 27.02 .20 & 04.03 .20 & 13.03 .20 & 27.03 .20 \\
\hline \multicolumn{8}{|c|}{ Sausages made of heat-treated ingredients: } \\
\hline \multirow{4}{*}{1} & \multirow{4}{*}{$\begin{array}{l}\text { Lebărvurști } \\
\text { c/l; }\end{array}$} & Initially & \multirow{4}{*}{$\max .70,0 / 70,0$} & 61,8 & 61,7 & 59,0 & 58,2 \\
\hline & & 5 & & 61,0 & 60,9 & 58,3 & 57,5 \\
\hline & & 7 & & 60,3 & 60,2 & 57,6 & 56,7 \\
\hline & & 10 & & 59,8 & 59,6 & 57,0 & 56,2 \\
\hline \multicolumn{4}{|c|}{ Difference between initial and 10 days of storage. } & 2,0 & 2,1 & 2,0 & 2,0 \\
\hline \multicolumn{4}{|c|}{$\mathrm{X} \pm \mathrm{Sx}$} & $60,725 \pm 0,324$ & $60,60 \pm 0,375$ & $57,975 \pm 0,368$ & $57,150 \pm 0,396$ \\
\hline \multicolumn{8}{|c|}{$\begin{array}{c}\text { Reproducibility, } \mathrm{R}, \%=2,77 \times \mathrm{S}_{\mathrm{R}}=2,5 \\
\text { Standard deviation of reproducibility, } \mathrm{S}_{\mathrm{R}} \%=0,9 \\
\text { Compound standard uncertainty }(\mathrm{k}=95 \%) \cup, \%=1,8\end{array}$} \\
\hline
\end{tabular}

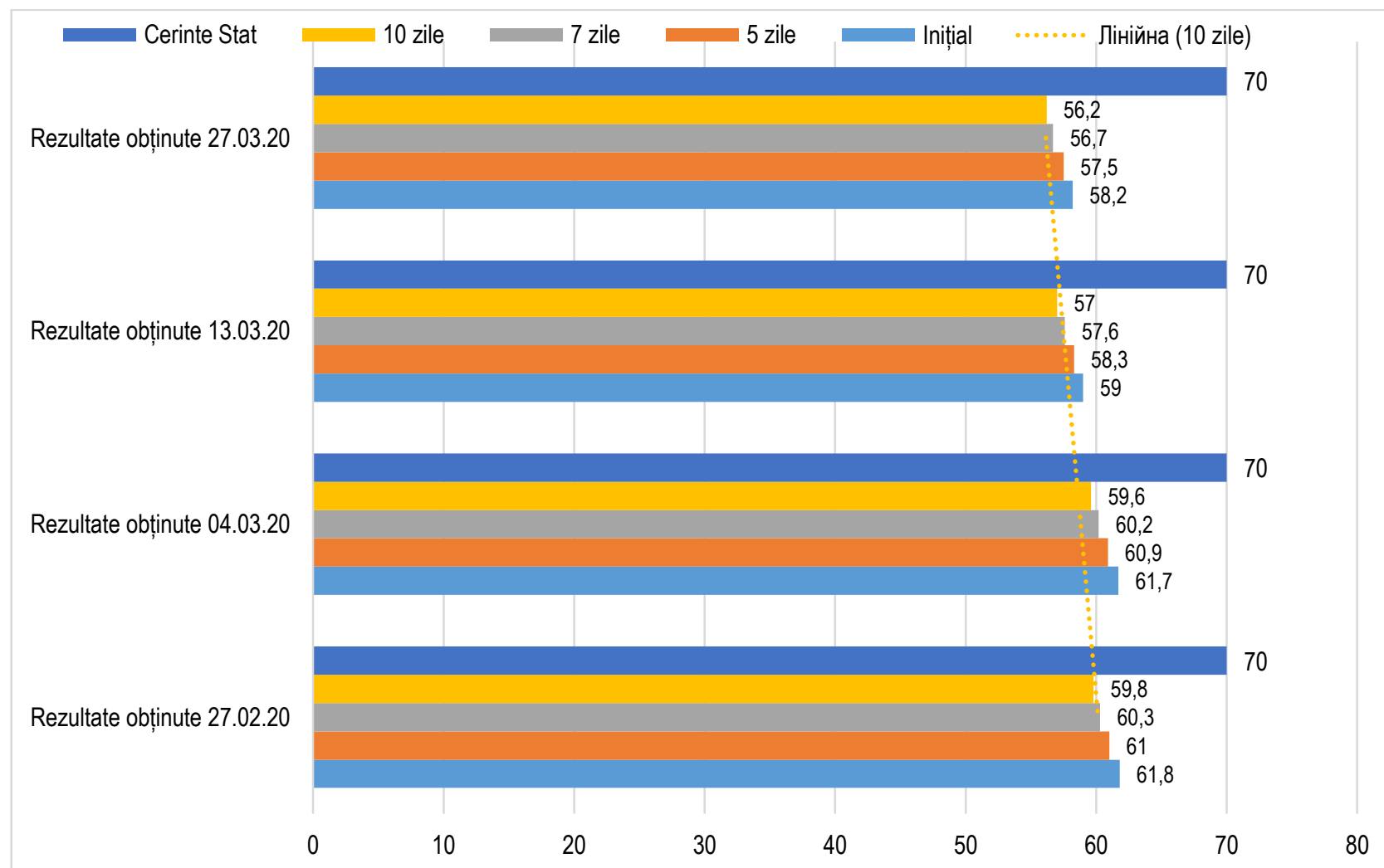

Fig. 3 Humidity value during the storage period \% - Lebărvurști

\section{State reqiurements 10 days 7 days 5 days Initially Linear(10 days)}

Regarding the evolution of humidity mass fraction during storage for the assortment of boiled meat product - Lebărvurști, it can be mentioned that the same tendency of slight decrease of humidity is observed from the beginning to the end of 10 days storage period, registering values from $59.8-56.2 \%$. The results show us an insignificant humidity decrease of the mass fraction at the end of the storage period and confirm that the results obtained fall within the admissible requirements of the normative acts in force, GD no. 720 of 28.06.2007 and CS to this category of products.

The change in humidity values, with a slight insignificant decrease of $1.1-2.1 \%$ at the end of the storage period (Figure 1; $2 ; 3$ ) of sausages made of heat-treated ingredients did not affect their quality. The appearance, consistency and taste did not change until the end of the storage period.

Thus, during the storage period of 10 days (taking into account the reserve ratio), meat products made of heat-treated ingredients did not undergo essential changes because at the end of the storage period the obtained results corresponded to the requirements of the normative documents in force for this product category.

As a result of the assessment of the physico-chemical indices in the meat products during the storage period - 7 days, it has been found out that their value did not change significantly and falls within the limits of the requirements of normative documents (GD no. 720 and CS for products). The quality of the products did not change, this fact was confirmed by the stability of the organoleptic indices at the end of the storage period.

\section{Microbiological indices}

In accordance with the normative documents in force GD no. 221 of 16.03 .2009 "Rules on microbiological criteria for food" and CS for products, microbiological investigations were 
performed at the beginning of the shelf life and over 5,7 and 10,5 days.

In order to guarantee the hygienic quality of the products, all microbiological indices were initially examined according to GD no. 221 and company's standards in all samples and their compliance was stated. Then during the storage period there were examined the microbiological indices, which could change the microflora and the quality of the product during its storage - Listeria monocytogenes, Bacteria coliforme, Number of colonies, E. Coli, yeasts and fungi.

During storage, in the examined meat products, the indices Listeria monocytogenes, Bacteria coliforme, E. Coli, yeasts and molds were not detected.

The microbiological index The number of colonies at $30^{\circ} \mathrm{C}$ varied for different products during the storage period (table 7).

Table 7

Dynamics of microbiological indices in the studied samples during storage period (10 days)

\begin{tabular}{|c|c|c|c|c|c|c|c|}
\hline $\mathrm{Nr}$. & Sample & Shelf life, days & Normative requirements CS & \multicolumn{4}{|c|}{ Number of colonies at $30^{\circ} \mathrm{C}, \mathrm{cfu} / \mathrm{g}$} \\
\hline \multicolumn{4}{|c|}{ Date of production } & 27.02 .20 & 04.03 .20 & 13.03 .20 & 27.03 .20 \\
\hline \multicolumn{8}{|c|}{ Sausages made of heat-treated ingredients: } \\
\hline \multirow{4}{*}{1} & \multirow{4}{*}{$\begin{array}{c}\text { Boiled pork } \\
\text { toba }\end{array}$} & Initially & \multirow{4}{*}{$\max .2,0 \times 10^{3}$} & $7,3 \times 10^{2}$ & $6,7 \times 10^{2}$ & $<10$ & - \\
\hline & & 5 & & $1,7 \times 10^{3}$ & - & $6,9 \times 10^{2}$ & - \\
\hline & & 7 & & $7,3 \times 10^{2}$ & - & $8,9 \times 10^{2}$ & - \\
\hline & & 10 & & $1,9 \times 10^{3}$ & $8,8 \times 10^{2}$ & - & - \\
\hline \multirow{4}{*}{2} & \multirow{4}{*}{ Pork Saltison } & Initially & \multirow{4}{*}{$\max .2,0 \times 10^{3}$} & $5,1 \times 10^{2}$ & $6,5 \times 10^{2}$ & $1,5 \times 10^{3}$ & $1,2 \times 10^{3}$ \\
\hline & & 5 & & $6,9 \times 10^{2}$ & - & $2,7 \times 10^{2}$ & $1,2 \times 10^{3}$ \\
\hline & & 7 & & $7,4 \times 10^{2}$ & - & $7,3 \times 10^{2}$ & $3,2 \times 10^{2}$ \\
\hline & & 10 & & $1,5 \times 10^{4}$ & $1,6 \times 10^{4}$ & - & - \\
\hline \multirow{4}{*}{3} & \multirow{4}{*}{ Lebărvurști c/l; } & Initially & \multirow{4}{*}{$\max .2,0 \times 10^{3}$} & $9,9 \times 10^{2}$ & $4,4 \times 10^{2}$ & $1,0 \times 10^{3}$ & $9,9 \times 10^{2}$ \\
\hline & & 5 & & $9,3 \times 10^{2}$ & - & $2,6 \times 10^{2}$ & $9,8 \times 10^{2}$ \\
\hline & & 7 & & $7,7 \times 10^{2}$ & - & $2,7 \times 10^{2}$ & $9,9 \times 10^{2}$ \\
\hline & & 10 & & $9,3 \times 10^{4}$ & $2,3 \times 10^{4}$ & - & - \\
\hline
\end{tabular}

In meat products Saltison and Lebervurști, on the 10th day of storage (including reserve coefficient) the number of colonies exceeded the limits of the standards requirements, but until the 7 th day of storage the values of this index remained in accordance with the requirements and did not exceed permissible $2 \times 103$ ufc / $\mathrm{g}$.

In meat products Boiled pork toba, the value of the number of colonies did not exceed the limits of the requirements of the normative documents during the storage period - 7 days.

Thus, following the assessment of the microbiological indices of meat products, it was established that they comply with the microbiological criteria and during the storage period their microflora did not change.

\section{CONCLUSIONS}

The research carried out within the LTFPAO of IPCRDV, in order to establish the shelf life of meat products Sausages made of heat-treated ingredients led to the formulation of the following conclusions:

1. The stability of the organoleptic indices, during the storage period (7 days), denotes a good quality of the product.

2. The physico-chemical indices have not changed considerably over time, remaining within the normative requirements even at the end of the storage period. The quality of the product was not affected.

3. Throughout the product storage period (7) days, the microbiological indices corresponded to the requirements of the normative documents.

4. Based on the performed research, for manufactured meat products the maximum shelf life of 7 days can be established from the date of manufacture, stored in the refrigerator at temperature $\mathrm{t}^{\circ} \mathrm{C}=0+6^{\circ} \mathrm{C}$ and the relative humidity of the air max. $75 \%$.

\section{References:} of foodstuffs.

1. Methodological guidance $-4.21847-04$ Sanitary-epidemiological assessment to justify the shelf life and storage conditions

2. Juravscaia, N. and others. Technical control of meat and meat products production. Kolos, Moscow, 2000;

3. Oprea A., Radu V. Control and expertise of food of animal origin. Bucharest, 2008.

4. Alisa Morari-Pîrlog.Processing meat products.Chisinau, 2017

5. Technical regulation "Meat products" GD.nr.720 of 28.06.2007

6. SM SR ISO 1442: 2014. Meat and meat products. Determination of humidity (Reference method). Chisinau, 2014.

7. SM ISO 21527-2: 2014. Microbiology of food and feed. Horizontal method for enumeration of yeasts and molds. Part 2:

8. SM EN ISO 4833-1: 2014. Microbiology of the food chain. Horizontal method for the enumeration of microorganisms.

9. SM ISO 4831: 2010. Microbiology of food and feed. Horizontal method for the detection and enumeration of coliform bacteria.

10. SM EN ISO 6579: 2015. Microbiology of food and feed. Horizontal method for detecting bacteria such as Salmonella spp.

11. GOST 9957-73 "Pork, sheep and beef products. Method for the determination of chlorides "

12. GOST 9959-91 "Meat products. General requirements for the evaluation of sensory indices".

13. GD no. 221 of 16.03.2009 "Rules on microbiological criteria for food".

14. GD no. 229 of 29.03 .2013 for the approval of the Sanitary Regulation on food additives.

15. SM SR ISO 1443: 2012. Meat and meat products. Determination of total fat content.

16. GOST 8558.1-78 "Meat products. Method for determining nitrites". 
17. GOST 31110-2002 "Meat and meat products. Spectrophotometric method for the determination of the mass fraction of total phosphorus".

18. SM EN ISO 11290-1: 2014 "Microbiology of the food chain. Horizontal method for the detection and enumeration of Listeria monocytogenes and Listeria spp. Part 1: Detection method.

19. GOST 29185 "Food products. Method for determining and counting sulfite-reducing clostridia ".

20. SM SR EN ISO 6888-1: 2013 "Microbiology of food and feed. Horizontal method for the enumeration of coagulasepositive staphylococci (Staphylococcus aureus and other species). Part 1: Baird-Parker Agar Technique

21. SM EN ISO 6579-1: 2017 "Microbiology of the food chain. Horizontal method for the detection, enumeration and serological typing of Salmonella bacteria. Part 1: Detection of Salmonella-like bacteria.

Пірлог Аліса Еміліянівна, кандидат сільськогосподарських наук, доцент, Державний аграрний університет Республіки Молдова (Кишинів, Молдова)

Куркі Діана Василівна, кандидат хімічних наук, завідувач лабораторії, Національний центр ветеринарної діагностики (Кишинів, Молдова)

Дослідження щодо продовження терміну зберігання до 7 днів термічно оброблених м'ясних продуктів, виготовлнних у відповідності до стандартів компанії і діючих технологічних інструкцій місцевих виробників

У сучасних ринкових умовах якість стала ключовим елементом в задоволенні вимог споживачів. Особливий інтерес представляє виробниитво продуктів з високими органолептичними характеристиками, які мають довгу перспективу збуту, з тривалим терміном зберігання, без зміни якості продукту. Щоб отримувати безпечні та якісно поживні продукти, нам потрібні нові технології та якісна сировина. Встановлення терміну придатності цих продуктів упродовж певного періоду часу допомагає продавати продукти харчування, які безпечні для споживача, а також з точки зору економічних міркувань виробників і безпеки харчових продуктів. Дослідження проводилося на асортименті ковбас, виготовлених з інгредієнтів шляхом термічної обробки, таких як: Lebărvurşti, I copm - упаковані в натуральній оболониі; Tobă de porc fiartă - упакована в поліамід, Saltison de porc - упакована в натуральну оболонку, призначені для громадського споживання з метою визначення якості, ффізико-хімічних і мікробіологічних показників, для вивчення можливості продовження терміну зберігання варених м'ясних продуктів до 7 днів, вироблених у відповідності з діючими стандартами і технологічними інструкціями м'ясопереробного підприємства. Таким чином, були отримані помітні результати за органолептичними характеристиками, такі як: зовнішній вигляд, консистенція, запах, колір, які відповідають вимогам норм, передбачених діючими нормативними актами для цих продуктів, за фізико-хімічними показниками можна відзначити, що вони не зазнали значних змін з плином часу, залишаючись у межах нормативних вимог і в кінці терміну придатності, не змінюючи якість продукту, а з точки зору мікробіологічних показників слід відзначити, що упродовж усього терміну придатності продукту - 7 днів, ці показники не змінилися, а продукти не зазнали змін і відповідали вимогам нормативних документів.

Ключові слова: м'ясні продукти, якість, безпека, термін придатності.

Дата надходження до редакції: 23.03.2021 р. 